\title{
The South China Sea Maritime Dispute: Legality, Power, and Conflict Prevention
}

\author{
Leszek Buszynski
}

Tensions in the South China Sea have risen in recent years for reasons related to conflicting territorial claims and rivalry, competition for access to fish stocks as well as oil and gas fields, and in China's case, emerging strategic interests. Because international law largely excludes it from an area it regards as historically Chinese, China has recently become more assertive in pushing its claim, resorting to power projection, particularly against smaller claimants, such as Vietnam and the Philippines. China's actions have drawn in external powers, including the United States, Japan, and India, a development that exacerbates the problem. The danger is not that the United States and China may come into a direct conflict, but that through error or miscalculation a clash may escalate into a conflict involving external powers. Proposals to prevent conflict and stabilize the area include an agreement to avoid incidents at sea. Also a UN-sponsored conference on the South China Sea could contribute to a long-term resolution of the issue by dealing with competing claims in a semi-enclosed sea and other outstanding issues.

Keywords South China Sea, UNCLOS, Law of the Sea, China, Vietnam, the Philippines

\section{Introduction}

The South China Sea is a semi-enclosed sea, which is defined in Article 122 of the United Nations Convention on the International Law of the Sea (UNCLOS) as "a gulf, basin or sea surrounded by two or more states and connected to another sea or the ocean by a narrow outlet or consisting entirely or primarily of the territorial seas and exclusive economic zones of two or more coastal States." It includes the 15 islands of the Paracel archipelago, 45 islands and numerous reefs and rocks of the Spratly archipelago, the Macclesfield Bank, and the three islands of the Pratas group. The dispute over the islands and sea territory involves China and five Association of Southeast Asian Nations (ASEAN) countries: Vietnam, the Philippines, Malaysia, Brunei, and Indonesia. China and Vietnam have extensive claims over the area that is largely undefined, while the Philippines,

(C) 2013 The Institute for Peace and Unification Studies, Seoul National University

E-ISSN 2288-2707 Print ISSN 2288-2693 
Malaysia, Brunei, and Indonesia claim contiguous sea zones. The dispute involves complicated issues relating to UNCLOS, which does not offer clear guidelines in situations where claims to sea territory, islands, and Exclusive Economic Zones (EEZs) overlap. This article examines the reasons for China's recent assertiveness in the area and identifies the impact upon the other claimants and upon external players. As a result of Chinese assertiveness, tensions have risen in the South China Sea, which heightens the risk of error or miscalculation and conflict. The article proposes ways to stabilize the situation in order to avoid unintended clashes that could lead to escalation, and examines ways in which the dispute might be resolved.

Factors in the dispute include fishing rights over stocks of migratory fish including albacore, skipjack, and yellowfin (Rosenberg 2011). Both Chinese and Vietnamese fishermen have long regarded parts of the Sea, particularly around the Paracel Islands, as traditional fishing zones. The United Nations (UN) has warned that fish stocks in the sea are in jeopardy as populations increase exacerbating competition to exploit the fisheries of the area (UN News Centre 2011). A second factor includes competing claims to oil and gas reserves as global demand for energy rises and major consumers, especially China, seek new sources to fuel their expanding economies. In 2011, China's oil imports accounted for about $54 \%$ of its total demand. To reduce its dependence on imported oil China has increased imports of natural gas and expanded the domestic production of coal, exacerbating the problem of atmospheric pollution in Chinese cities (International Energy Agency 2012). China has shown growing interest in the oil and natural gas resources of the South China Sea and its estimates of the oil reserves there have been much higher than those of multinational oil companies. Some Chinese estimates claim that the area holds some $80 \%$ of Saudi Arabia's oil reserves. However, the United States Department of Energy doubts this, declaring that "there is little evidence outside of Chinese claims to support the view that the region contains substantial oil resources." The Department adds that natural gas may be more important than oil in the South China Sea as the U.S. Geological Survey estimates that about " 60 to $70 \%$ of the region's hydrocarbon resources are natural gas" (U.S. Energy Information Agency 2008). Again, Chinese estimates of the area's natural gas reserves are considerably higher than others.

For China, there is also the strategic significance of the South China Sea since it is becoming a focal point for naval rivalry with the United States. From the Chinese perspective the U.S. naval presence in the Western Pacific prevents the reunification of Taiwan with the mainland, and for this reason it becomes imperative for China to develop the ability to prevent the U.S. navy from coming to Taiwan's assistance if there were to be a conflict. To this end, China has been developing a second strike submarine-based nuclear capability which would deter the United States from risking conventional conflict with China over Taiwan or any other issue. China has deployed a new generation of ballistic missile-carrying 
nuclear submarines (SSBNs) in the Jin class; each submarine would eventually deploy 12 JL-2 ballistic missiles (SLBMs) with a range of 7,400 kilometers, which could target Hawaii and the U.S. West Coast. The Chinese navy has constructed a major naval base at Yalong on Hainan Island that can accommodate nuclearpowered attack and ballistic-missile submarines, and aircraft carriers (U.S. Secretary of Defense 2012). From Hainan Island, access to the open sea is through the South China Sea making it an important corridor for the Chinese navy.

Moreover, the Chinese economy has become vulnerable to external disruption of oil and energy supplies, and this obliges its leaders to protect its extended trade routes and energy supply lines. Over $50 \%$ of China's crude oil imports come from countries in the Middle East, and an estimated $80 \%$ of its total oil imports is shipped through the Indian Ocean and the Malacca Straits. These routes are vulnerable to interdiction by India and the United States. In time of conflict, both may hold China to ransom by interrupting China's oil supplies. To protect its sea lanes and energy supplies, China has decided to develop a blue ocean naval capability, including aircraft carriers and accompanying escorts which could patrol as far as the Indian Ocean (Zhang 2006). This naval capability is best deployed in a way that allows access to the southwest, thus making Hainan Island the most suitable base. For these reasons, China requires control over the South China Sea, or at least the capability to prevent potentially hostile naval forces from threatening access by its navy to the open sea (Yoshihara and Holmes 2010, 141-42; Buszynski 2012).

If the dispute was only about maritime borders or access to oil and gas deposits, it could be settled by a mutual adjustment of claims, in much the same way that China and Vietnam negotiated a settlement over their border in the Gulf of Tonkin in 2000. However, the strategic factor has become more important to China as its naval capability has expanded to take on new missions that go beyond the traditional role of coastal defense. This factor engages the interests and lobbying efforts of the People's Liberation Army Navy (PLAN) and tends to make Chinas attitude towards the issue less flexible. The dispute may have been resolvable in earlier years, but since the strategic factor has emerged in China's calculation of interests that prospect has become remote.

\section{Legality}

The problem for China is that the existing legal framework does not support its claim to the South China Sea. According to international law, sovereignty over territory is demonstrated by continuous, peaceful and effective occupation, or by displays of sovereignty such as acts of state administration (Van Dyke 2009, 3975). This principle was laid down in the Island of Palmas Case by the Permanent Court of Arbitration on April 4, 1928, and has been affirmed in various ways 
since then. In the El Salvador/Honduras case of 1992 the International Court of Justice (ICJ) examined the evidence of possession, control, and the display and exercise of sovereignty, coupled in each case with the position of the other party, to decide which islands belonged to Honduras and which to El Salvador (ICJ 1992). In the Malaysia/Indonesia dispute over Ligitan and Sipadan, the ICJ in 2002 noted Malaysias efforts to regulate and control the collection of turtle eggs, and its maintenance of lighthouses constructed in the colonial era on both islands. It decided that these were acts of administration that revealed an "intention to exercise state functions in respect of the two islands" (ICJ 2002).

China's claim to the South China Sea is based on its U-shaped line that was published in April 1935 by the Republic of China's Land and Water Maps Inspection Committee. When promulgated in 1947, the map had 11 dashes, but two dashes in the Gulf of Tonkin area were removed by the People's Republic of China in 1953, probably in order to accommodate Vietnam over Bai Long Wai Island, leaving nine dashes today (see Figure 1). China has given no official explanation of the nine-dash line-whether it is a claim to islands or sea territory within the lines, or whether it represents the exact boundaries of China's claim. One Chinese interpretation is that it is a claim for islands and represents China's "traditional maritime boundary" in the South China Sea (Li and Li 2003). The U-shaped line, however, does not conform to legal requirements and cannot be regarded as a legitimate maritime boundary. Another Chinese view suggests that it is "not a boundary line of territorial waters and is non-exclusive," and that it does not prevent freedom of flight or navigation and does not conflict with EEZs or continental shelves (Tang 2013). In May 2009, China attached a map that included the U-shaped line with its nine dashes to its diplomatic note to the UN Commission on the Limits of the Continental Shelf in protest against Vietnamese and Malaysian joint submission. This was the first time that the ninedash line was used in an official communication (Zou 2012; Zou 2005, 47-60). To have legal validity, maps should be incorporated in a treaty, and should conform to certain definitional requirements in terms of clarification of boundaries and the content of the claim (Miyoshi 2012). The Chinese have recognized the legal weakness of the $\mathrm{U}$-shaped line, and convened a team of scholars from both Taiwan and the mainland to strengthen its legal validity in 2012. The President of the National Institute for South China Sea Studies (NISCSS), Wu Shicun, has said that the intention is to give the international community a legal explanation of the U-shaped line within one year (Xinhuanet 2012b).

China cannot demonstrate that it has exercised administrative functions over the area or the islands within it. It occupies the Paracel Islands and nine islands in the Spratlys over which it may claim to exercise these functions, but not the entire area. China insists that it has rights of first discovery to the area. However, while Chinese historical sources mention the Paracels, the references to the Spratly Islands are contestable, as China had little contact with them historically. 
Figure 1. China’s Nine-dash Line

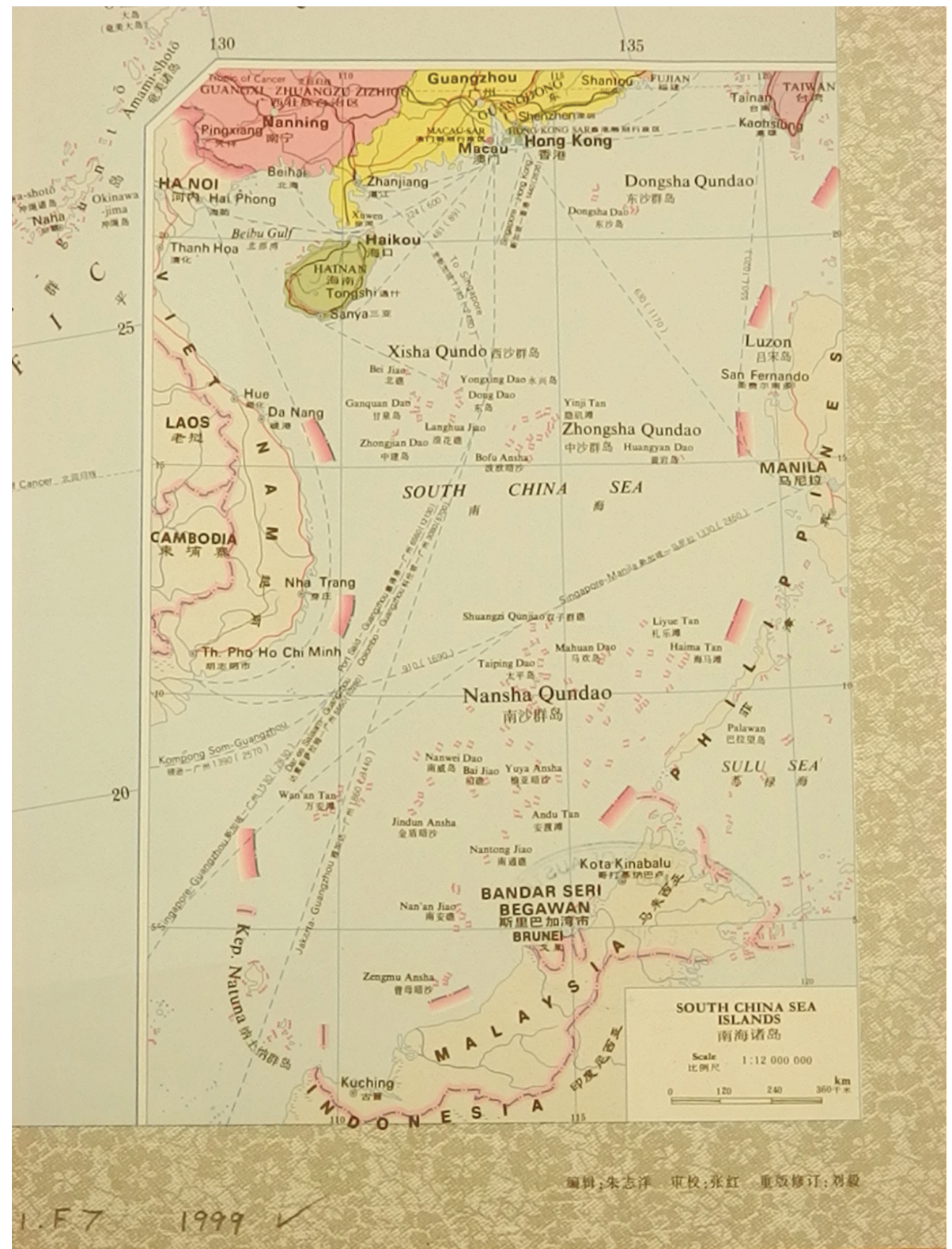

Source: Courtesy of National Library of Australia.

China's trade route to the West went through the Paracel Islands and along the Vietnamese coast, while the galleon trade with Spain went to the Philippines and then to Acapulco in Mexico. The Spratly area was bypassed in both cases (Ptak 2004, 120; Samuels 2005, 22). During the Qing dynasty China first raised 
its claim to the South China Sea as a result of the war with France (1884-85), but in this case Chinese interest focused on the Paracels, not the Spratlys. There is evidence that China regarded the Paracels as its southern border, as reflected in Shin P'eng Fei's 1928 Paracels Commission Report (Samuels 2005, 22). China only developed an interest in the Spratlys as a response to the French intrusion in 1933, when France claimed the area, and later when the Japanese occupied some of the islands in 1939. The San Francisco Treaty of August 1951 divested Japan of all rights over the area, but China protested because the treaty did not affirm its sovereignty. Since then, China has insisted that the South China Sea had always been Chinese territory.

Indeed, no claimant can demonstrate continuous and effective control and administration of the islands to satisfy the legal criteria. Vietnamese, Philippine, and Malaysian claims are of recent origin, and their validity is dependent upon a determination of the prior status of the area and the islands they have occupied. As the ICJ noted in the El Salvador/Honduras case, if the islands were not terra nullius beforehand then sovereignty over them could not be acquired by occupation. Vietnam occupies 21 islands in the Spratly area and has supplied maps and administrative records to demonstrate historical contact with the South China Sea, but they reveal contact only with the Paracels and not with the Spratly Islands (Valencia, Van Dyke, and Ludwig 1997). The Philippine claim is based on contiguity and the continental shelf, the occupation of eight islands which were considered terra nullius, and its Presidential Decree No. 1596 of June 11, 1978, which declared sovereignty over what was called the "Kalayaan Island Group" (Granados 2009; Yorac 1983). There are various difficulties with the Philippine claim aside from the issue of whether the islands were terra nullius. Unilateral declarations of sovereignty carry little legal weight on their own, and contiguity is no argument in international law. The continental shelf claim is weakened by the fact that there is no natural prolongation, as required by Article 76 of UNCLOS, since the deep Palawan Trough separates the Spratlys from the Philippine archipelago (Valencia, Van Dyke, and Ludwig 1997, 30). Malaysia occupies five islands and faces the same obstacle of determining their status before their occupation. It bases its claim on the continental shelf as depicted in a map published in 1979 that shows territorial waters and continental shelf boundaries. Brunei claims an EEZ that overlaps with the Malaysian claim, while Indonesia claims an EEZ around the Natuna Islands that overlaps with the Chinese claim (see Figure 2).

China claims historical rights over the area based on first discovery. The difficulty is that international law does not support claims based on first discovery or contact against claims that can demonstrate effective and uninterrupted occupation. In the Island of Palmas case, Spain claimed title based on first discovery, but the court decided that "it is not sufficient to establish that a title was validly acquired at a specific moment, but it must be shown that sovereignty was 
Figure 2. CIA Map of South China Sea Claims

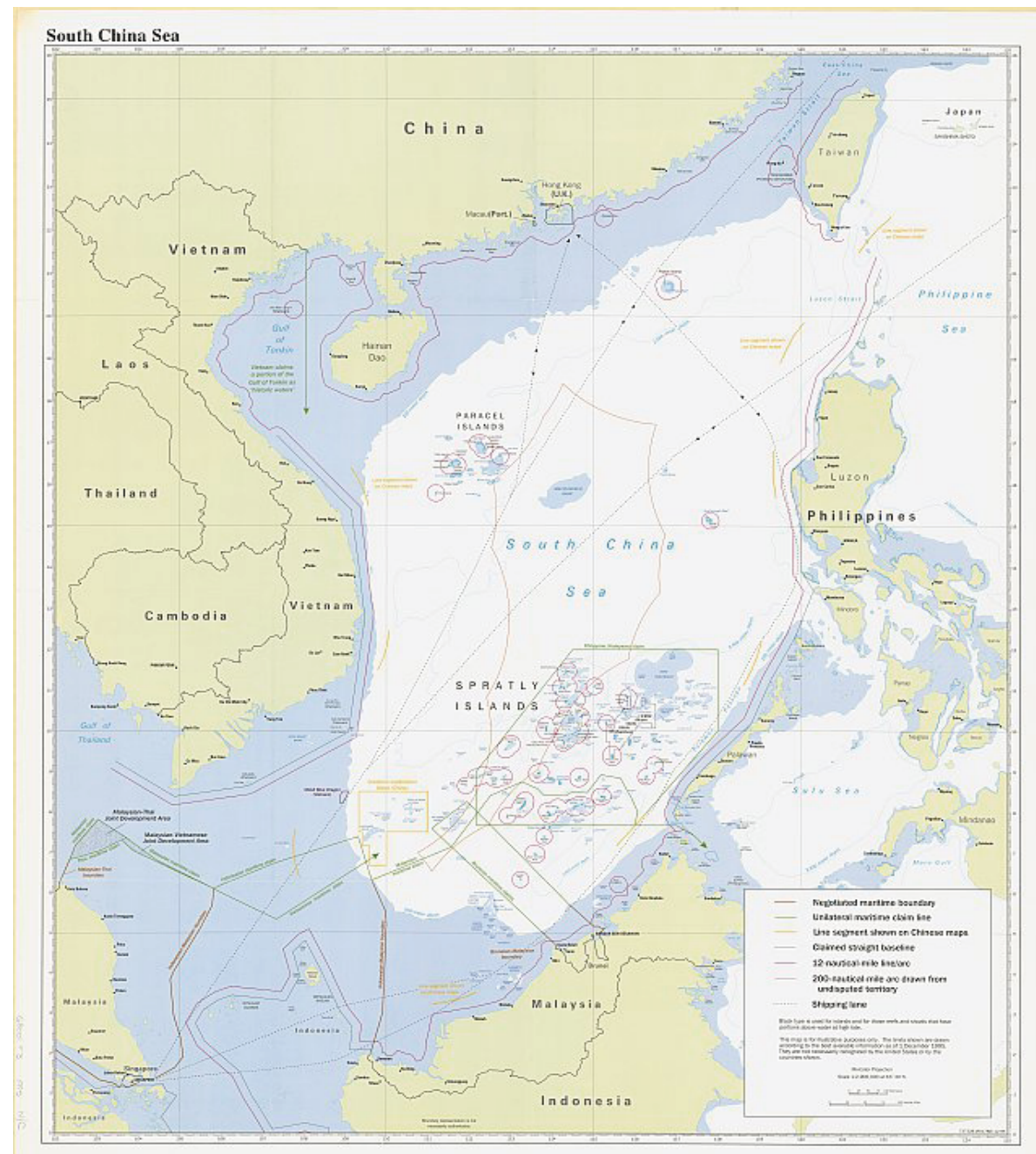

Source: Courtesy of the National Library of Australia.

held continuously." If Spain had title to the island, it was lost to the Netherlands because it failed to maintain continuous administrative functions over the island (Permanent Court of Arbitration 1928). This principle was upheld in the Eritrea-Yemen case when Yemen stressed the importance of "ancient title" to the islands in dispute. While the court did not dismiss the notion of ancient title, it referred to the Palmas precedent and used the test of the "continuous display of governmental authority and presence" to decide ownership of the islands (Permanent Court of Arbitration 1998). In a situation where its legal claim to the South China Sea is questionable, China has been stressing its historical rights 
based on first discovery and contact. China's law on the EEZ and the Continental Shelf of June 26, 1998, stated that those historic rights would be unaffected by UNCLOS, which seemed to indicate an intention to revise international law, but it was unclear how this might be done (Zou 2012; Zou 2005, 157-74). A historic claim may have less authority than is required by UNCLOS, since it would depend upon what could be proven according to historical records. For this reason, the trend in China is to merge both historic and legal rights to support these claims. Accordingly, China can invoke UNCLOS to claim EEZs and continental shelves, and to make up for any shortfall it can call upon historic rights that would allow an extended claim up to the U-shaped line (Hong 2012). Still, UNCLOS does allow for "historic bays" under Article 10 according to strict criteria, but the concepts of historic rights or historic waters find little support in law. ${ }^{1}$

China, nonetheless, has continued to assert its historic rights over the South China Sea. The Chinese often declare that their historical notions of sovereignty predate Western international law and should be recognized as valid ab initio. Chinese commentaries argue that UNCLOS cannot be applied to the South China Sea since China had "indisputable sovereignty" over the area to begin with (Deng 2012). This broad rejection of international law where China's historic claims to the area are concerned raises doubts about China's commitment to UNCLOS. It also conflicts with the approach adopted by Chinese scholars who recognize both UNCLOS and historic rights as a basis for China's claim. The view that international law should accommodate historical claims has some support in East Asia; some proponents argue that claims of sovereignty in Asia should not be judged by "norms developed in Europe" (Lee 2009). In a similar vein, these proponents argue that China had its own concept of maritime space and possession, which cannot be judged in terms of Western law. To establish possession, these scholars argue that it should be sufficient to identify what Ming and Qing China officials understood as their maritime boundaries (Suganuma 2000).

Particular difficulties arise in the modern era in attempting to prove historic claims; it would certainly be insufficient simply to assert them ignoring the legal procedures developed by modern international law. If competing claims are made based on historical title, and all are seemingly valid in their own terms, who will arbitrate between them and according to what criteria? Moreover, when claims based on ancient title lie dormant and are then revived, and they are challenged by claims based on principles developed by modern international law, how would a legal body decide between them? Modern international law offers objective criteria to decide between conflicting claims, without which the result would be confusion. Ancient records and a subjective understanding of possession alone are insufficient to decide sovereignty, without evidence that such possession was recognized by others. Indeed, inter-temporal law refers to Justice Max Huber's 
tests in the Palmas case to the effect that historical title should be assessed according to the criteria of the past, and any rights so obtained may be lost "if not maintained in accordance with the changes brought about by the development of modern international law" (Elias 1980). Without this requirement the law would fail to clarify complicated situations, and the result would be a slide towards using state power to force recognition of a claim. That slide has been noticeable in the South China Sea over the past few years.

\section{Power}

China's shift to use of power should be explained in a wider context. Since 2009, China's behavior over the South China Sea, and towards Japan over the Senkaku/ Diaoyu Islands, and also in relation to North Korea, has indicated a pattern of greater assertiveness and insistence upon national interests. One interpretation is opportunism: China has taken advantage of the global financial crisis that weakened the United States to advance Chinese interests in these areas. Chinese resentment of the U.S. military presence in the Western Pacific, and the U.S. alliances with Japan and South Korea, were factors prompting Beijing to assume a tougher position. In relation to the South China Sea, the assertiveness may be related to increasing capabilities to promote China's long-standing claim, which is indicative of a greater role for the military in Chinese foreign affairs (Swaine and Taylor 2000). The senior party leaders may control foreign and defense policy issues, but they do not have clear control or oversight over military actions at the operational level that can shape or undermine policy. Naval operations beyond China's territorial borders, deployment of Chinese naval vessels into the territorial waters of other countries, interception of U.S. surveillance vessels operating near China, and military exercises conducted in the South China Sea and elsewhere, are all the business of the military, and they are undertaken with considerable autonomy (Swaine and Taylor 2000). This is not to say that the military exerts decisive influence over policy (which is clearly not the case), but that the professional autonomy of the military allows it to frame its own operating goals within the policy parameters set by the party leadership. The absence of effective coordination between the civilian and military sectors in the Chinese decisionmaking system ensures that military activities assume a life of their own from which foreign ministry officials and Chinese scholars are excluded. What this means for the South China Sea case is that the strategic factor and the importance of naval deployments, supported by popular nationalism invoked by party officials and the mass media, increasingly shape Chinese attitudes towards the issue. The result is that the issue, which in the 1990s was regarded as negotiable, has become decidedly non-negotiable for the Chinese.

Chinese officials have said that because China had not insisted on its rights 
in the past a false impression had been created that it was not defending its maritime interests, and this impression had to be corrected by assertiveness (Kenji 2010). This assertiveness has been seen in the harassment tactics employed by the Chinese to intimidate the ASEAN claimants into accepting its claims. Encouraged by senior party leaders, local provincial authorities and agencies within China have scrambled to obtain their share of the South China Sea resources with the conviction that they belong to China, and to prevent the ASEAN claimants from exploiting the area. Some ASEAN diplomats suggest that prolonged Chinese harassment in the South China Sea is intended as a demonstration to the ASEAN claimants that they are not capable of supporting their own claims to the South China Sea. In such a scenario they would be obliged to settle with China and accept its dominant position in the area. The best interpretation of China's actions is that it seeks to hustle the ASEAN claimants into a legal settlement based on renunciation or adjustment of their existing claims in recognition of China's historical claims. China may then allow the ASEAN claimants some access to the resources to ensure their compliance with the arrangement. The worst-case interpretation, as suggested by Vietnamese officials, is that China would seek exclusive control over the area and the removal of the ASEAN claimants through a prolonged campaign of increasing harassment. In this case, China would attempt to impose a settlement by power. $^{2}$

Chinese maritime surveillance vessels have been discouraging major oil companies, whose oil exploration vessels have been contracted by ASEAN claimants, from operating in the area, obliging them to seek permission from China (Guinto and Ten Kate 2012). Vietnam has complained of regular incidents when Chinese maritime surveillance vessels severed the exploration cables of Vietnamese survey ships; such incidents were reported on May 26 and June 9, 2011, and November 30, 2012. China has also imposed an annual fishing ban around the Paracels from May 16 to August 1. Vietnam has vociferously protested, claiming that its fishermen are regularly arrested by Chinese patrol vessels, their vessels confiscated, and an exorbitant fine demanded for their release (South China Morning Post 2010). To enforce the ban and to protect its own fishing vessels China has dispatched converted naval craft, called "fishery patrol" vessels, to the South China Sea; this preserves the appearance of routine administrative action rather than naval activity which could raise the stakes. These vessels include the 4,500-ton Yuzheng 311, Yuzheng 202 (later sent to the Senkaku/Diaoyu and replaced by the Yuzheng 301), and Yuzheng 302, as well as the modern Haixun 21 and Haixun 31.

In 2011, the Philippines reported seven incidents involving Chinese harassment. On March 2, two Chinese patrol boats harassed an oil exploration ship in the Philippine claim zone 250 kilometers west of the Island of Palawan, and only left the area after the Philippine air force was scrambled. On April 5, the Philippines lodged a formal protest at the UN, to which the Chinese 
responded by accusing the Philippines of invading China's waters (Cerojano 2011). China deployed one of its most modern fishery patrol vessels, the Haixun 31, to the area while the Philippines dispatched its naval flagship, the World War II vintage Rajah Humabon (Burgonio 2011). In 2012, Forum Energy announced that the Sampaguita gas field in Reed Bank had more gas than initially expected, which prompted Manila to issue contracts for their exploitation. The gas reserves of Reed Bank were first discovered in 1976 and have been contested by China ever since. At one time a Chinese vessel threatened to ram a survey vessel hired by a Philippine energy company, Philex Petroleum (Dela and Mogato 2012). A major standoff occurred with the Philippines on April 8, 2012 near Scarborough Shoal when two Chinese maritime surveillance vessels prevented a Philippine coast guard vessel from arresting Chinese fishermen poaching in the Philippine claim zone. AntiChina demonstrations were held in Manila while the Chinese cancelled group tours to the Philippines and purchase orders for Philippine bananas. China's Ambassador to ASEAN, Tong Xiaoling, insisted that the reef had been Chinese since "ancient times," and waters around the island were traditional fishing grounds for Chinese fishermen (Xu 2012). Counter demonstrations were held in China and the nationalist Chinese newspaper, Global Times, declared that the Philippines had to be taught a lesson for its "aggressive nationalism," and that China had to ensure victory "even if it means it may cost more than imagined" (Global Times 2012). The standoff eased after the Philippines withdrew its two coast guard vessels by June 15; and on June 25 Philippine Foreign Secretary Alberto del Rosario reported that more than 20 Chinese fishing boats had withdrawn from the area (Esplanada 2012). However, Philippine Defense Secretary Voltaire Gazmin noted that the Chinese had roped off entry into the lagoon at Scarborough Shoal to prevent Philippine fishermen from entering (Tubeza and Burgonio 2012). China's actions prompted the Philippines to appeal to arbitration, and on January 22, 2013, it notified China that it was bringing the dispute before an arbitral tribunal under Annex VII of UNCLOS (Brage 2013; Washington Times 2013; Philippine Embassy - Canberra). Predictably, the Chinese rejected the appeal.

China has gone further to assert its claim over the South China Sea by announcing plans to increase its maritime surveillance forces to 16 aircraft and 350 vessels by 2015. Vessels such as the 3,000-ton Haixun 11 and Haixun 31 will support the smaller Haijian 84 and Haijian 72 maritime surveillance vessels, boosting China's presence and capability in the area. In 2012, China's State Oceanic Administration reported that 58 patrol missions were conducted in the South China Sea, and these missions are expected to increase. Their purpose will be to monitor shipping to carry out surveying duties, to "protect maritime security," and to inspect foreign vessels operating in "Chinese waters" (Wang 2011). In February 2013, three Chinese naval vessels entered the South China 
Sea from the North China Sea Fleet to carry out patrol missions and training exercises in China's "territorial waters" (Xinhua 2013). Clearly the Chinese authorities are aiming to create the conviction among the Chinese public that the South China Sea has always been Chinese, as much as Taiwan or any other territory of China, and it is now described as China's "territorial waters." What was once an outlying sea area for China has been elevated to the status of "Chinese territory," becoming a focal point for a volatile Chinese nationalism for which historical distinctions and the rights of other claimants are irrelevant (Mcdonald 2012). Beginning in April 2012, the U-shaped line appeared on new Chinese passports as part of a map of China to buttress this conviction amongst the Chinese public. In response, Vietnam and the Philippines have begun to issue separate visas to Chinese visitors to avoid appearing to acquiesce to the Chinese claim. In July 2012, China also created a showpiece assembly of 45 deputies to administer the Paracels and Spratly Islands in the new city of Sansha in Hainan province (Xinhuanet 2012a). Hainan province announced new rules governing the area and stated that, beginning January 1, 2013, Chinese maritime police would board and search vessels conducting "illegal" activities in "Chinese waters" (Blanchard and Mogato 2012). The announcement stimulated much concern amongst the ASEAN claimants, especially since the Director General of the Foreign Affairs Office of Hainan Province, Wu Shicun, said that the rules covered all the land features inside the nine-dash line and adjacent waters. He further said that Chinese ships would be allowed to search and repel foreign ships if they were engaged in "illegal" activities within the 12-nautical-mile zone surrounding islands that China claims (Perlez 2012). The intention was to act against what the Chinese called "illegal" Vietnamese fishing in the Paracels area. The concern, however, was that if China were to enforce these rules, freedom of navigation in the wider South China Sea, which is of direct concern to external powers such as the United States and Japan, would be restricted. The rules were announced by a provincial authority and may be overridden by Beijing if they result in difficulties; but it is just as likely that the rules will be upheld by central authorities if they effectively demonstrate what is off limits for the ASEAN claimants. In time, then, the Chinese claims may be accepted by others simply to avoid trouble with Beijing. In January 2013, China published national maps that included the South China Sea and Taiwan together with the mainland, making them appear an integral part of China's national territory. Without access to objective information about the situation, the Chinese public would imagine that the South China Sea was always part of China, just like any other province.

Chinese scholars and foreign ministry officials often stress that China is prepared to negotiate the issue and that Beijing has always stood for "negotiation of international disputes through peaceful means" (Wang 2013). Chinese Vice Foreign Minister Fu Ying claimed that China has consistently attempted to resolve the dispute through friendly negotiations between sovereign countries and 
that the Philippines was to blame for the increase in tensions (China Daily 2012). Foreign ministry officials are simply repeating old statements out of habit when in fact the time for negotiation has passed for China. The invocation of nationalism, and the publication of maps which treat the South China Sea as an integral part of China, show that the intention is not to negotiate, but to affirm China's claims and to put ASEAN claimants on notice accordingly. China's new leader Xi Jinping has revealed a tough position in relation to these maritime disputes in the South China Sea as well as the Senkaku/Diaoyu Islands. In a speech in December 2012, China's new leader stressed firmness in "safeguarding China's sovereignty, security and territorial integrity," though he also mentioned that China would resolve differences with neighbors peacefully "through friendly negotiations" (Li 2012). It is difficult to see how China could insist on its claim in no uncertain terms and at the same time offer to negotiate with the ASEAN claimants-unless the intention is to obtain their endorsement of the Chinese position. Xi has also stressed his ties with the Chinese military, which serves as the ultimate guarantor of the party leadership as it faces fissiparous tendencies in a rapidly changing society that could challenge its authority. Xi succeeded $\mathrm{Hu}$ Jintao as party chief and chair of the Central Military Commission in November 2012, and has already made nine visits to army units and commanders. He also made a brief visit to a destroyer in the South China Sea, and met commanders of China's strategic nuclear missiles (Buckley 2013). As China's new leader strengthens his links with the military to ensure regime survival, it is very unlikely that he would curb its activities or its deployment of naval vessels in disputed areas, or challenge its understanding of the strategic value of the South China Sea.

China's harassment tactics in the South China Sea have drawn in the United States and other external powers increasing the risks and the uncertainty. The United States is troubled by China's assertiveness, and its broader interests cause several concerns. One concern is that a dominant China would exclude American energy companies from exploration and drilling in the area. A second is that control over the South China Sea could trigger the fragmentation of ASEAN, whose unity has supported a favorable regional order conducive for the American presence. ASEAN was divided over the issue in April 2012 when Cambodia, as ASEAN Chair, opposed the Philippine demand to place the South China Sea on the agenda of the 20th ASEAN summit in Phnom Penh. Cambodia has been accused of acting as a proxy for China, which has invested some two billion US dollars in the country, building infrastructure, roads, and dams for which its leader, Hun Sen, is keen to show his gratitude. In July 2012, the 45th ASEAN Foreign Ministers Meeting failed to issue a communiqué because it could not come to agreement over the issue. The issue found a place in the chairman's statement of the 21st ASEAN summit in November 2012, but the damage had been done, and ASEAN disunity over the issue had been revealed. A third concern is that a dominant Chinese position in the area would allow China to 
threaten the sea lanes of the Western Pacific, and the oil lifelines of Japan and South Korea. China's ability to threaten the sea lanes would be enhanced if Taiwan rejoined the mainland, in which case pressure on Japan and Korea to accommodate China in various ways would be increased. Japan in particular would be alarmed, and though the Japanese may re-route their sea shipments of oil and material though the Indonesian straits, costs would rise significantly. A fourth concern is that China may gain strategic advantages by dominating the South China Sea, increasing the operational reach of its growing navy. China's assertiveness in the South China Sea was an important factor behind the Obama Administration's rebalancing policy, also called the pivot strategy, of rearranging military forces in the Asia region, which was announced in November 2011 (U.S. Department of Defense 2012). This would entail moving some 9,000 marines from Okinawa to places like Guam, Australia and the Philippines on rotation, and developing closer security relationships with Indonesia and Vietnam, which share similar concerns about China. Due to its proximity to the South China Sea, the Philippines has assumed a key role in the United States rebalancing strategy. In November 2012, Secretary of State Hillary Clinton told Philippine Foreign Affairs Secretary Alberto del Rosario that "any nation with a claim has a right to exert it, but they do not have a right to pursue it through intimidation or coercion" (Whaley 2012b). The Philippines will offer the United States greater access to its airfields and will receive surveillance data in return. U.S. naval vessels are expected to receive maintenance, repair and logistics support at Subic Bay, which the Americans vacated in 1992. The United States also decided to triple Foreign Military Financing for the Philippines in 2012, from 11.9 million US dollars to 30 million dollars to help it build a "credible minimum defense posture" (Mogato 2012). The United States has transferred two 3,250-ton Hamilton-class naval cutters to the Philippines for coast guard duties, and a third will follow along with a squadron of secondhand F-16s (Whaley 2012a).

Japan is also becoming involved. Under pressure from the Chinese in the Senkaku/Diaoyu Islands dispute, where China is adopting similar harassment tactics, Japan has moved to strengthen security cooperation with both Vietnam and the Philippines. In a diplomatic effort to strengthen ties with Southeast Asia, Japan's newly elected Prime Minister Shinzo Abe visited Vietnam, Thailand, and Indonesia, on his first overseas trip abroad after his election in January 2013. In the same month Japan's Foreign Minister Fumio Kishida visited the Philippines, Singapore, Brunei, and Australia. As the Asahi Shimbun (2013) noted: "It is vital for countries facing challenges posed by China's growing economic and military power to bolster their cooperation." Japan announced that it will donate patrol boats to the Philippines; Filipinos expect to receive 12 vessels, at least two of which will be 1,300-ton Hateruma-class patrol vessels. The Japanese coastguard intends to train Philippine and Vietnamese personnel to boost security cooperation. 
Similarly, India has become involved to protect its oil companies that have contracted with the Vietnamese for exploration and survey work in the area. India also can use the South China Sea as a pressure point against China over other longstanding issues that concern it, such as the festering border dispute in the Himalayan region, and China's as yet limited presence in the Indian Ocean. External Affairs Minister S.M. Krishna, in April 2012, declared: "India maintains that (the) South China Sea is the property of the world. [...] those trade ways must be free from any national interference" (Economic Times 2012). Indian navy chief Admiral D.K. Joshi, has stated that the navy may be deployed to the South China Sea where the Indian oil company, Oil and Natural Gas Corporation, has a stake in a gas and oil exploration block in the Nam Con Son basin off the coast of Vietnam (Business and Finance News 2012).

China cannot force the issue of the South China Sea with Vietnam and the Philippines without further increasing tensions and involving external powers more deeply in the disputes. Neither the United States nor Japan would become immediate actors in any dispute, and a direct U.S.-China clash in the area is not on the cards. However, their anxiety over threats to freedom of navigation would prompt their involvement as supporters of the ASEAN claimants and as suppliers of arms and weapons to the Philippines. Since Secretary of State Hillary Clinton took up the issue at the ASEAN Regional Forum in July 2010, the United States has provided the ASEAN claimants with moral support, encouraging them to resist China. The Chinese may calculate that the United States has too much at stake in maintaining good relations with them to confront it over this issue, but that would be a risky assumption. The uncertainty of the American response could act as a deterrent to overt Chinese action, as could the possibility of greater security cooperation between the United States, Japan, and the ASEAN claimants. While China may avoid direct action in the area, the main risk of the South China Sea dispute is not conflict with the United States, but error or miscalculation on the part of local Chinese commanders that may draw in the United States. These local commanders may act on the basis of an assertive nationalism that they have been encouraged to believe in and support. The risk of miscalculation poses real dangers, particularly as China has not developed an effective crisis management system that would overcome the compartmentalization of the civilian and military sectors. China's slow response to crisis situations was revealed during the accidental NATO bombing of the Chinese Embassy in Belgrade in May 1999, and the EP-3 surveillance aircraft incident of April 2001. In the latter case a Chinese J-8 fighter collided with a U.S. EP-3E Aries signals intelligence aircraft that was engaged in surveillance off the coast of Hainan and the U.S. plane was forced to land on the island. What was disturbing about the incident was the delay in the Chinese response, which led to speculation that President Jiang Zemin was being fed a distorted version of events that justified a tough Chinese reaction. Deputy Secretary of State Richard Armitage disclosed that American efforts to resolve 
the incident quickly through behind-the-scenes phone calls at a high level were unsuccessful as the Chinese would not answer the phone. It was only 11 days later, after Colin Powell expressed "regret" over the incident to meet the Chinese demand for an apology, that the crew of the aircraft were released (Kan et al. 2001). The crisis passed, but it left an indelible impression of a Chinese decisionmaking system that could not respond effectively to crises.

\section{Stabilization and Conflict Prevention}

The immediate priority is to stabilize the situation in the South China Sea and prevent accidental conflict in disputed areas, particularly as China increases deployment of patrol craft there. ASEAN concluded a Declaration on a Code of Conduct (COC) for the South China Sea with China on September 2, 2002, which was a statement of broad principles of behavior. ASEAN's intention was to move to a legally binding COC and not just a statement of principles, which China has resisted. Chinese officials have argued that since the South China Sea is Chinese territory anyway, a COC is not relevant. While China holds to this belief, the prospects for the COC are not bright. Another approach is to negotiate Incidents at Sea Agreements (INCSEA) to avoid naval clashes in these areas and to prevent accidental escalation if clashes occur. These agreements would detail procedures to avoid collisions between patrol vessels by ensuring safe distance from each other, and would require commanders to use caution in approaching other vessels. They would also include procedures for communication between navies and governments in the event of a clash, and the establishment of hotlines between the naval commands or coast guards in the area. The most notable example is the INCSEA between the United States and the Soviet Union, concluded on May 25, 1972, after a series of incidents at sea involving harassment, simulated attacks and dangerous maneuvers (Bureau of International Security and Nonproliferation 1972). On January 19, 1998, the United States and China concluded an agreement to ensure maritime safety, which called for consultations, and measures to improve maritime practices and communications procedures when vessels encounter each other (Federation of American Scientists 1998). Though a step in the right direction something more concrete is required under the present circumstances. China may be reluctant to consider an INCSEA that would limit its freedom of action, but its perspective might change if it were to face the consequences of an accidental clash or a crisis.

Can the dispute be resolved? Vietnamese officials who were asked this question were adamant that no resolution was possible at this time since China's intention to control the entire South China Sea was consistent and unwavering. Nonetheless, they do acknowledge that there are limits to China's activities, as China is dependent upon the prevailing international economic order and would 
not go so far as to cause serious disruption. This gives some hope for a resolution of the dispute. ${ }^{3}$ Various well-meaning proposals have been aired to bring about a resolution, but most have been outdated and rendered meaningless by recent events. The obvious approach is to seek a legal resolution of the dispute which entails the application of UNCLOS principles according to an agreed equitable formula that would take into account the claims of the littoral states. According to Articles 74 and 83 of UNCLOS-III, in the case of overlapping EEZs and continental shelves, delimitation will be effected by agreement on the basis of international law or by appeal to the International Court of Justice to "reach an equitable solution." Both articles mention that if no agreement is reached within a "reasonable period of time" then the parties "shall resort" to the dispute resolution procedures in Part XV. Based on UNCLOS, a logical approach would be to apportion maritime territory according to contiguous EEZs and continental shelves, where they have been declared, and to use coastline lengths to determine the maritime zones that occupied islands would be entitled to. Aside from the practical difficulties of arranging the apportionment, the major problem is that neither China nor Vietnam has defined its claims. China's U-shaped line has not been officially explained; whether it is a claim to islands or an exclusive claim to sea territory is unclear, and its exact boundaries are still undefined. Vietnam has issued declarations of sovereignty over islands without specifying exactly what is included in this claim or what the coordinates are. Moreover, these proposals would significantly reduce the maritime area available to China, which would be stripped of its claim to the entire area with little compensation, particularly as the oil and gas fields are outside the central area in areas that fall in the EEZs of the ASEAN claimants.

Within ASEAN, joint development was regarded as a way of overcoming the sovereignty imbroglio: If claimants could be induced to cooperate over oil and gas extraction perhaps they would learn to overcome their differences over sovereignty through a cooperative solution. The idea was first broached by Chinese Premier Li Peng in Singapore on August 13, 1990, when he called upon claimants to set aside sovereignty to enable joint development to proceed. The Chinese Premier wanted to improve relations with ASEAN after alarms were raised by the clash with Vietnam in the South China Sea in March 1988 and by the Tiananmen Square events of June 1989. Joint development has been repeatedly raised by Chinese Foreign Ministry officials but without further clarification. One agreement came close when the Joint Marine Seismic Undertaking Accord was concluded in March 2005 between China National Offshore Oil Company, the Vietnam Oil and Gas Corporation, and the Philippine National Oil Company (People's Daily 2005). It was simply a three year agreement for joint seismic exploration, but it was strongly criticized by the Philippine side because the area of activity was mainly in the Philippine claim zone. Since then Chinese Vice Foreign Minister Fu Ling perfunctorily mentioned joint 
development in an interview in September 2012, but the time for it has long since passed (Ling 2012).

Third party mediation has also been raised as a possibility, since Article 287 of UNCLOS enjoins parties to a maritime dispute to resort to four dispute resolution mechanisms: the International Tribunal for the Law of the Sea in Hamburg; the International Court of Justice in The Hague; ad hoc arbitration in accordance with Annex VII; or a "special arbitral tribunal" constituted for certain categories of disputes. Compulsory mediation with binding authority is voluntary, and UNCLOS has no immediate way of dealing with a situation where the claimants have no intention of resorting to binding mediation. The only attempt to invoke third party mediation over the dispute occurred on January 22, 2013, when Philippines Foreign Secretary Albert del Rosario announced that the Philippines would take the issue to an arbitral tribunal under Annex VII of UNCLOS (Department of Foreign Affairs 2013). The move has the support of the United States but the Chinese predictably opposed it, without Chinese representation it would be unlikely that the case would be heard. International lawyers suggest that the tribunal could appoint a representative for China, but this would simply create new difficulties, as China may disown the proceedings.

The idea of a cooperative maritime regime has often been raised; this would entail a mutual adjustment of claims and a sharing of resources under an authority or body created for this purpose. A maritime regime is a cooperative effort to regulate behavior in a given area according to agreed rules and norms, which give effect to the notion of a common good. Article 123 of UNCLOS stipulates that states "bordering an enclosed or semi-enclosed sea should cooperate with each other in the exercise of their rights and in the performance of their duties under this Convention," and the article adds that they should do so "directly or through an appropriate regional organization." An appropriate regional organization could be a Spratly Resource Development Authority, or a Spratly Management Authority, which would grant permits for exploration and joint development; it could have a secretary general, a secretariat, and a council. The Authority would direct the financial resources of claimants into a common fund to promote joint efforts to develop the area's oil and gas fields (Valencia, Van Dyke, and Ludwig 1997). The idea of a cooperative regime has appeal, but its implementation requires agreement between the claimants and prior resolution of their claims; it is a product of a resolution of the issue, not a means to bring about a resolution. It may act as an incentive to the claimants to resolve their claims, but its acceptance would require a political decision, a step that would be particularly difficult for China.

Proposals for a cooperative maritime regime would carry greater weight if they were endorsed by a UN-sponsored conference on the South China Sea that involved China and the ASEAN claimants in the first instance, as well as external stakeholders. Such a conference would reveal the legal weaknesses of the claims, 
including the U-shaped line, and would seek their cooperative adjustment. The agenda would also include the formation of a regional body, or cooperative regime, that would adopt rules regarding fishing practices and quotas, oil and gas exploration, and the passage of naval vessels in the maintenance of freedom of navigation. Held under UN auspices, the conference would ensure conformity to international law and would restrain any temptation to depart from it to accommodate superior power. Philippine President Fidel Ramos in 1992, proposed an international conference on the Spratlys under UN auspices; the proposal was mentioned again by Philippine Foreign Secretary Raul Manglapus at the ASEAN Foreign Ministers meeting, in July 1992. However, the Chinese Foreign Ministry quickly voiced its opposition, and the proposal has not been raised since. China has consistently rejected multilateral negotiations of the issue in the past and may continue to insist that the South China Sea is Chinese territory. However, the incentive for China to join this process of resolution is the legalization of its position and stabilization of the area while reducing the prospect of raising tensions or increasing the risk of instability. China will not gain legal acceptance of its claim by power alone, but through a conference of this kind would gain shared access to the resources in the area. China would repair its relationship with ASEAN and would earn the gratitude of the organization, which would be more likely to come to terms with China over this and other issues as well. It would ease the regional polarization created by China's attempt to gain unilateral benefits in the sea by resorting to power. China would also avoid pushing the ASEAN claimants to seek support from the United States and Japan, and would give external powers no cause to cooperate against China. A resolution of this kind would also remove the main motive for America's pivot strategy, stimulating cooperation rather than rivalry with the United States. Indeed, in such a scenario China's regional position would be enhanced and its international credibility elevated.

\section{Conclusion}

China's policy toward the South China Sea is reflected not only in the public statements of Foreign Ministry officials and senior party leaders who call for peace, joint development, and friendly negotiations. Despite these public statements what China wants to do is not so easily identified. China's intentions are closely linked to the opportunities created by its activities in the area, as undertaken by the Chinese navy, provincial authorities, and maritime surveillance agencies. These activities which include harassment tactics and lowlevel confrontation, shape China's position for as long as they are not disowned by the party leadership. Indeed, these activities are the instruments of Chinese policy, and China's objectives would expand according to their success, or they 
could be curtailed if significant dangers were revealed. As China continues with these tactics and naval deployments in the area, greater instability and uncertainty may be expected. In other cases, when governments have been locked into seemingly unyielding positions, they have been compelled to change when faced with the prospect of conflict or crisis escalation. Crises can have a shock effect upon political leaders who become aware of the dangers of continuing with familiar behavior, thus demanding of them major changes of policy and attitude. At the present moment it seems that only a crisis will trigger the necessary change of attitudes over the South China Sea, particularly within China. At that point the proposal for a UN-sponsored conference on the South China Sea would become more meaningful.

\section{Notes}

1. 'Historic waters' as such did not and do not exist as an independent institution in the law of the sea." See Land, Island, and Maritime Frontier Dispute (El Salvador/Honduras: Nicaragua intervening), Judgment of September 11, 1992, I.C.J. Reports 1992, [588-89] 351-83. Max Planck Institute for Comparative Public Law and International Law. http:// www.mpil.de/ww/en/pub/research/details/publications/institute/wcd.cfm?fuseaction wcd=aktdat\&aktdat $=202030000200 . \mathrm{cfm}$ (accessed March 5, 2013).

2. Interviews with Vietnamese officials, Hanoi, April 8 and 9, 2013.

3. Interviews with Vietnamese officials, Hanoi, April 8 and 9, 2013.

\section{References}

Asahi Shimbun. 2013. "Editorial: Abe Should Not Try to Divide Asia Countries into Friends and Foes." January 15.

Blanchard, Ben, and Manuel Mogato. 2012. "Chinese Police Plan to Board Vessels in Disputed Seas." Reuters, November 29. http://www.reuters.com/article/2012/11/29/ us-china-seas-idUSBRE8AS05E20121129 (accessed April 1, 2013).

Brage, Pia Lee. 2013. "Phl Takes Sea Row with China to UN." The Philippine Star, January 23.

Buckley, Chris. 2013. "New Chinese Leader Shores Up Military Support." The New York Times, March 3.

Bureau of International Security and Nonproliferation. 1972. "Agreement between the Government of the United States of America and the Government of the Union of Soviet Socialist Republics on the Prevention of Incidents on and over the High Seas." Washington, D.C.: U.S. Department of State. May 25. http://www.state.gov/t/isn/4791. htm (accessed December 23, 2012).

Burgonio, T. J. 2011. "Navy Flagship to Patrol PH Waters Only, Says Palace." Philippine Daily Inquirer, June 21.

Business and Finance News. 2012. "Indian Navy Prepared to Deploy to South China Sea to 
Protect Oil Interests." December 3.

Buszynski, Leszek. 2010. "Rising Tensions in the South China Sea: Prospects for a Resolution of the Issue." Security Challenges 6 (2): 85-104.

Buszynski, Leszek. 2012. "The South China Sea: Oil, Maritime Claims, and US-China Strategic Rivalry.” Washington Quarterly (Spring): 139-56.

Cerojano, Teresa. 2011. “Beijing Counters Manila’s UN Protest, Says Philippines 'Started to Invade' Spratlys in 1970s.” AFP, April 19.

Charney, Jonathan I. 1995. "Central East Asian Maritime Boundaries and the Law of the Sea." The American Journal of International Law 89 (4): 724-49.

China Daily. 2012. "Sea Issue Should be Resolved by Concerned Parties." August 5. http:// usa.chinadaily.com.cn/world/2012-08/05 (accessed September 25, 2012).

Dela, Cruz Erik, and Manuel Mogato. 2012. "RPT-Manila Firm Finds Gas in South China Sea; May Fuel China Tension.” Reuters, April 24. www://reuters.com/assets/ print?aod=USL3E8FO1ND20120424 (accessed September 25, 2012).

Deng, Shasha. 2012. "Commentary: A Law-twisting, Reality-distorting Charge against China over South China Sea." Xinhuanet, August 17.

Department of Foreign Affairs. 2013. "Statement by Secretary of Foreign Affairs Albert del Rosario on the UNCLOS Arbitral Proceedings against China to Achieve a Peaceful and Durable Solution to the Dispute in the WPS." The Department of Foreign AffairsRepublic of the Philippines. January 28. http://www.dfa.gov.ph/index.php/newsroom/ dfa-releases?start=98 (accessed April 5, 2012).

Economic Times. 2012 "South China Sea Property of World: SM Krishna." April 7. http://articles.economictimes.indiatimes.com/2012-04-07/news/31304909_1_oilexploration-asean-south-china-sea (accessed December 10, 2012).

Elias, Taslim Olawale. 1980. “The Doctrine of Intertemporal Law.” The American Journal of International Law 74 (2): 285-307.

Energy Information Administration. 2008. "South China Sea, Oil and Natural Gas." http:// www.eia.doe.gov/emeu/cabs/South_China_Sea/OilNaturalGas.html (accessed January 20, 2013).

Esplanada, Jerry E. 2012. "China Fishing Boats Leave Scarborough Shoal-DFA." Inquirer news, June 26.

Federation of American Scientists. 1998. "China on Establishing a Consultative Mechanism to Strengthen Military Maritime Safety." January 19. www.fas.org/nuke/control/sea/ text/us-china98.htm (accessed December 10, 2012).

Global Times. 2012. “Peace Will Be a Miracle If Provocation Lasts.” May 9.

Granados, Ulises. 2009. "Ocean Frontier Expansion and the Kalayaan Islands Group Claim: Philippines' Postwar Pragmatism in the South China Sea." International Relations of the Asia-Pacific 9 (2): 267-94.

Guinto, Joel, and Daniel Ten Kate. 2012. "Oil Majors Avoid Philippine Bids for Chinaclaimed Sea Blocks." Bloomberg Business Week, July 31. http://www.businessweek. com/news/2012-07-30/philippines-to-offer-offshore-oil-blocks-in-china-claimedareas (accessed December 10, 2012).

Hong, Nong. 2012. "Interpreting the U-shape Line in the South China Sea." China \& US Focus, May 15. http://www.chinausfocus.com/peace-security/interpreting-the-ushape-line-in-the-south-china-sea/ (accessed January 5, 2013).

International Court of Justice. 1992. "Case Concerning Land, Island and Maritime Frontier 
Dispute (El Salvador/Honduras: Nicaragua Intervening).” September 11. http:// www.icjcij.org/docket/index.php? sum $=390 \& \operatorname{code}=$ sh $\& \mathrm{p} 1=3 \& \mathrm{p} 2=3 \&$ case $=75 \& \mathrm{k}=0 \mathrm{e}$ \&p3=5 (accessed December 10, 2012).

International Court of Justice. 2001. "International Decision: Maritime Delimitation and Territorial Questions between Qatar and Bahrain (Qatar v. Bahrain).” March 16. http://www.icj-cij.org (accessed December 10, 2012).

International Court of Justice. 2002. "International Court Finds that Sovereignty over Islands of Ligitan and Sipadan belongs to Malaysia." ICJ/60517 December. The Hague: International Court of Justice. http://www.un.org/News/Press/docs/2002/ ICJ605.doc.htm (accessed December 10, 2012).

International Energy Agency. 2012. "Oil and Gas Emergency Policy-China 2012 Update.” http://www.iea.org/publications/freepublications/publication/China_2012.pdf (accessed December 10, 2012).

International Law Commission. 1964. "Juridical Regime of Historic Waters, including Historic Bays." Yearbook of the International Law Session 1962 II. Document A/CN.4/143. New York: United Nations. http://untreaty.un.org/ilc/publications/ yearbooks/Ybkvolumes\%28e\%29/ILC_1962_v2_e.pdf (accessed December 10, 2012).

Kan, Shirley A., Richard Best, Christopher Bolkcom, Robert Chapman, Richard Cronin, Kerry Dumbaugh, Stuart Goldman, Mark Manyin, Wayne Morrison, Ronald O’Rourke Foreign Affairs, Defense, and Trade Division. 2001. China-U.S. Aircraft Collision Incident of April 2001: Assessments and Policy Implications. CRS Report for Congress, Order Code RL30946. Washington, D.C.: The Library of Congress.

Kenji, Minemura. 2010. "China to Establish Permanent Senkaku Patrols." Asahi Shimbun, December 20.

Lee, Sekwoo. 2009. "Intertemporal Law, Recent Judgements and Territorial Disputes in Asia." In Maritime Boundary Disputes, Settlement Processes, and the Law of the Sea, eds. Seoung-Yong Hong and Jon M. Van Dyke. Leiden and Boston: Martinus Nighoff Publishers, 119-37.

Li, Jinming, and Dexia Li. 2003. “The Dotted Line on the Chinese Map of the South China Sea: A Note." Ocean Development and International Law 34 (3-4): 287-95.

Li, Ling. 2012. "Xi Jinping Uses Tougher Tone on South China Sea Disputes at Asean Meeting." South China Morning Post, September 22. http://www.scmp.com/news/ china/article/1042712/xi-jinping-uses-tougher-tone-south-china-sea-disputes-aseanmeeting (accessed December 10, 2012).

Ling, Fu. 2012. "Vice Foreign Minister of PRC Fu Ying's Interview with the Straits Times and Lianhe Zaobao." Embassy of the People's Republic of China in the Republic of Singapore, September 10. http://www.chinaembassy.org.sg/eng/xwdt/t967803.htm (accessed December 16, 2012).

Mcdonald, Mark. 2012. "A New Map in Chinese Passports Stirs Anger Across the Region." The New York Times, November 25.

Miyoshi, Masahiro. 2012. “China's 'U-Shaped Line' Claim in the South China Sea: Any Validity Under International Law?” Ocean Development \& International Law 43 (1): $1-17$.

Mogato, Manuel. 2012. “US Triples Military Aid to Philippines in 2012.” Reuters, May 3. www.reuters.com/assets/print?aid=USBRE8420IU20120503 (accessed January 22, 
2013).

People's Daily. 2005. "Philippines, China, Vietnam to Conduct Joint Marine Seismic Research in South China Sea.” March 15. http://english.peopledaily.com. cn/200503/15/eng20050315_176845.html (accessed December 26, 2012).

Perlez, Jane. 2012. "Alarm as China Issues Rules for Disputed Area." The New York Times, December 1.

Permanent Court of Arbitration. 1928. "The Island of Palmas Case (Miangas): The Netherlands v. United States of America." 2 U.N. Report. Int'l Arbitral Awards 829. http://web.archive.org/web/20041215063650/http://ksumail.kennesaw.edu/ cli/palm. htm (accessed December 10, 2012).

Permanent Court of Arbitration. 1998. "Territorial Sovereignty and Scope of the Dispute (Eritrea and Yemen).” Reports of International Arbitral Awards XXII: 209-332.

Philippine Embassy-Canberra. "Q \& A on the UNCLOS Arbitral Proceedings against China to Achieve a Peaceful and Durable Solution to the Dispute in the West Philippine Sea." http://www.philembassy.org.au/q-a-a-on-the-unclos-arbitralproceedings-against-china-to-achieve-a-peaceful-and-durable-solution-to-thedispute-in-the-west-philippine-sea.html (accessed January 22, 2013).

Prime Minister of Japan and Cabinet. 2012. "Press Conference by the Chief Cabinet Secretary (Excerpt)." Opening Statement by Chief Cabinet Secretary Fujimura, the Prime Minister of Japan and his Cabinet, September 10. http://www.kantei.go.jp/ foreign/tyoukanpress/201209/10_p.html (accessed January 22, 2013).

Ptak, Roderich. 2004. China, the Portuguese, and the Nanyang: Oceans and Routes, Regions and Trade (c1000-1600). Aldershot: Ashgate Variorum.

Rosenberg, David. 2011. "Governing the South China Sea: From Freedom of the Seas to Ocean Enclosure Movements.” Harvard Asia Quarterly (December): 1-12.

Samuels, Marwyn S. [1982] 2005. Contest for the South China Sea. New York: Routledge.

Shambaugh, David. 2011. "Coping with a Conflicted China." The Washington Quarterly (Winter): 7-27.

South China Morning Post. 2010. “Unilateral Fishing Ban Likely to Fuel Tension.” May 17.

South China Morning Post. 2013. "Japan to Give Patrol Boats to Manila amid China Tensions." February 14.

Suganuma, Unryu. 2000. Sovereign Rights and Territorial Space in Sino-Japanese Relations: Irredentism and the Diaoyu/Senkaku Islands. Honolulu: University of Hawaii Press, 115-54.

Swaine, Michael D., and Fravel M. Taylor. 2000. China's Assertive Behavior Part Two: The Maritime Periphery. China Leadership Monitor no. 35. Carnegie Endowment for International Peace. http://carnegieendowment.org/files/CLM35MS.pdf (accessed December 23, 2012).

Tang, Ifang. 2013. “On the Dotted Line." Beijing Review, February 21.

Tubeza, Philip C., and T.J. Burgonio. 2012. "China Ropes off Scarborough Shoal." Philippine Daily Inquirer, August 3.

UN News Centre. 2011. "Fish Demand Reaches All-Time High but Global Stocks Still LowUN Agency." January 11. http://www.un.org/apps/news/story.asp?NewsID=37421\#. US6iAqVBOT4 (accessed December 23, 2012).

U.S. Department of Defense. 2012. "Defense Secretary Panetta's Remarks on Defense Strategic Guidance." Washington, D.C.: Office of the Assistant Secretary of Defense 
(Public Affairs). January 5. http://iipdigital.usembassy.gov/st/english/texttrans/201 2/01/20120105163808su0.3729451.html\#axzz1uFNKZNca (accessed December 23, 2012).

U.S. Energy Information Agency. 2008. "Chinese Claim It Holds 80\% of Saudi Arabia’s Oil Reserves.” http://www.eia.gov/emeu/cabs/South_China_Sea/pdf.pdf (accessed December 23, 2012).

U.S. Secretary of Defense. 2012. "Annual Report to Congress: Military and Security Developments Involving the People's Republic of China." DIA-02-1109-276. Washington, D.C.: Office of the Secretary of Defense. http://www.defense.gov/pubs/ pdfs/2012_CMPR_Final.pdf (accessed January 22, 2013).

Valencia, Mark J., Jon M.Van Dyke, and Noel A. Ludwig, 1997. Sharing the Resources of the South China Sea. Leiden and Boston: Martinus Nijoff.

Van Dyke, Jon M. 2009. "Disputes over Islands and Maritime Boundaries in East Asia." In Maritime Boundary Disputes, Settlement Processes, and the Law of the Sea, eds. Seoung-Yong Hong and Jon M. Van Dyke. Leiden and Boston: Martinus Nijhoff, 3975.

Vietnamnet. 2011. "Diplomatic Note 1958 with Vietnam's Sovereignty over Paracel, Spratly Islands." July 21. http://english.vietnamnet.vn/en/special-report/10961/diplomaticnote-1958-with-vietnam-s-sovereignty-over-paracel--spratly-islands.htm (accessed December 26, 2012).

Wang, Qian. 2011. "Maritime Forces to be Beefed up Amid Disputes." China Daily, June 17. http://www.chinadaily.com.cn/china/2011-06/17/content_12718632.htm(accessed December 26, 2012).

Wang, Yuanuan. 2013. "China Stresses Negotiations to Settle Disputes.” Xinhua, January 23. http://news.xinhuanet.com/english/video/2013-10/23c_1321211485.hml (accessed January 23, 2013).

Washington Times. 2013 "Shoal at Center of Territorial Spat." January 22.

Watts, Alex. 2011. “Tensions Rise as Vietnam Accuses China of Sabotage." Sydney Morning Herald, June 2.

Whaley, Floyd. 2012a. "Philippines Role May Expand as US Adjusts Asia Strategy." The New York Times, April 29.

Whaley, Floyd. 2012b. "Clinton Reaffirms Military Ties with the Philippines." The New York Times, November 16.

Xinhua. 2013. "Navy Enters South China Sea for Patrol, Training." February 1. http://www. china.org.cn/china/Off_the_Wire/2013-02/01/content_27862467.htm (accessed February 11, 2013).

Xinhuanet. 2012a. "Legislative Conference Held in Newly Established City in South China Sea." July 23.

Xinhuanet. 2012b. "Chinese Scholars to Study South China Sea Borderline, Says Expert." October 24.

Xu, Tianran. 2012. "Manila Moves to Quell Spat." Global Times, May 15.

Yorac, Haydee B. 1983. "Philippine Claim to the Spratly Islands Group." Philippine Journal of Law 58 (2): 42-63.

Yoshihara, Toshi, and James R. Holmes. 2010. Red Star over the Pacific: China's Rise and the Challenge to US Maritime Strategy. Maryland: Naval Institute Press.

Zhang, Wenmu. 2006. "Sea Power and China's Strategic Choices." China Security 3 
(Summer): 17-31. http://www.chinasecurity.us/index.php?option=com_csissues\&seci $\mathrm{d}=20 \&$ catid $=62 \&$ task $=$ catetory\&Itemid $=8$ (accessed February 11, 2013).

Zhi, Chen. 2013. "China Publishes New Maps: South China Sea Islands Highlighted." Xinhuanet, January 11. http://news.xinhuanet.com/english (accessed January 20, 2013).

Zou, Keyuan. 2005. Law of the Sea in East Asia: Issues and Prospects. New York: Routledge. Zou, Keyuan. 2012. "China's U Shaped Line in the South China Sea Revisited." Ocean Development \& International Law 43 (1): 18-34.

Leszek Buszynski is Visiting Fellow with the National Security College at the Australian National University, Canberra, Austalia. He has been researching the South China Sea dispute for two decades and has recent publications include "Chinese Naval Strategy, the United States, ASEAN and the South China Sea," Security Challenges (2012), "The South China Sea: Oil, Maritime Claims, and U.S.-China Strategic Rivalry," The Washington Quarterly (2012), and "Rising Tensions in the South China Sea: Prospects for a Resolution of the Issue," Security Challenges (2010). 
